\title{
Article \\ Can Anthropometry and Body Composition Explain Physical Fitness Levels in School-Aged Children?
}

\author{
Chih-Yu Hsu ${ }^{1} \mathbb{D}$, Liang-Sien Chen ${ }^{1}$, I-Jen Chang ${ }^{1}$, Wei-Ching Fang ${ }^{1}$, Sun-Weng Huang ${ }^{2,3}{ }^{\circledR}$, Rong-Ho Lin ${ }^{2}$, \\ Steve Wen-Neng Ueng ${ }^{4,5}$ and Hai-Hua Chuang ${ }^{1,2,4,6, *}$ (1)
}

1 Department of Family Medicine, Linkou and Taipei Branches, Chang Gung Memorial Hospital, Taoyuan 33305, Taiwan; b85079@gmail.com (C.-Y.H.); m7090@cgmh.org.tw (L.-S.C.); Drchangijen@gmail.com (I.-J.C.); winds75526@gmail.com (W.-C.F.)

2 Department of Industrial Engineering and Management, National Taipei University of Technology, Taipei 10608, Taiwan; t107379004@ntut.org.tw (S.-W.H.); rhlin@mail.ntut.edu.tw (R.-H.L.)

3 Graduate Institute of Urban Planning, College of Public Affairs, National Taipei University, New Taipei City 23741, Taiwan

4 College of Medicine, Chang Gung University, Taoyuan 33302, Taiwan; wenneng@adm.cgmh.org.tw

5 Department of Orthopedic Surgery, Linkou Main Branch, Chang Gung Memorial Hospital, Taoyuan 33305, Taiwan

6 Obesity Institute, Geisinger, Danville, PA 17837, USA

* Correspondence: chhaihua@gmail.com; Tel.: +886-975-366-509

Citation: Hsu, C.-Y.; Chen, L.-S.; Chang, I-J.; Fang, W.-C.; Huang, S.-W.; Lin, R.-H.; Ueng, S.W.-N.; Chuang, H.-H. Can Anthropometry and Body Composition Explain Physical Fitness Levels in School-Aged Children? Children 2021, 8, 460 . https://doi.org/10.3390/ children 8060460

\section{Academic Editors:}

Odysseas Androutsos and

Antonis Zampelas

Received: 30 April 2021

Accepted: 26 May 2021

Published: 31 May 2021

Publisher's Note: MDPI stays neutral with regard to jurisdictional claims in published maps and institutional affiliations.

Copyright: (c) 2021 by the authors. Licensee MDPI, Basel, Switzerland. This article is an open access article distributed under the terms and conditions of the Creative Commons Attribution (CC BY) license (https:/ / creativecommons.org/licenses/by/ $4.0 /)$.

\begin{abstract}
Physical fitness (PF) is closely related to various health outcomes and quality of life among children. However, the associations between anthropometry, body composition (BC), and PF are not fully elucidated. This cross-sectional study aimed to investigate the associations between demographic metrics (age, sex), anthropometric measures (body mass index z-score (BMI z-score) waist/height ratio (WHtR)), BC parameters (body-fat percentage (BF\%), muscle weight), and PF levels (800-m run, sit-and-reach, 1-min sit-ups, standing long jump) in school-aged children. Continuous variables were dichotomized by median splits. The results of 180 girls and 180 boys (mean age: $10.0 \pm 0.7$ years; mean BMI z-score: $0.366 \pm 1.216$ ) were analyzed. Multivariable linear regressions revealed that $\mathrm{BF} \%$ (regression coefficient $(\mathrm{B})=3.4,95 \%$ confidence interval $(\mathrm{CI})=2.5-4.3$ ) was independently correlated with the 800-m run. Sex $(B=4.6,95 \% C I=3.0-6.3)$, age $(B=3.1,95 \%$ $\mathrm{CI}=1.9-4.3)$, and $\mathrm{BMI} z$-score $(\mathrm{B}=-0.7,95 \% \mathrm{CI}=-1.4--0.1)$ were independently related to sitand-reach. Age $(\mathrm{B}=3.3,95 \% \mathrm{CI}=2.0-4.7), \mathrm{BF} \%(\mathrm{~B}=-0.3,95 \% \mathrm{CI}=-0.4--0.2)$, and muscle weight $(B=0.7,95 \% C I=0.2-1.2)$ were independently associated with 1 -min sit-ups. In addition to demography, anthropometry and BC provided additional information concerning some PF levels in school-aged children. Weight management and PF promotion should be addressed simultaneously in terms of preventive medicine and health promotion for children.
\end{abstract}

Keywords: anthropometry; body composition; children; epidemiography; physical fitness

\section{Introduction}

Physical fitness (PF) is defined as one's capability to work effectively, enjoy leisure time, be healthy, resist hypokinetic diseases, and meet emergencies [1,2]. PF also displays the body's ability to function efficiently. A substantial volume of research has been conducted in adults on the relationships between PF and various health outcomes [3]. The literature suggests that a lack of physical activity (PA) or poor PF is associated with a wide range of chronic diseases [4]. PF is an important predictor for adiposity, bone health, premature mortality, diabetes, cardiovascular diseases, metabolic syndrome, and mental health [3,5-8].

Among all the PF metrics, cardiorespiratory and muscular fitness seem to be the two most influential parameters for disease and health [9]. Low cardiorespiratory fitness is associated with metabolic syndrome, diabetes, and an increased prevalence of cardiovascular disease $[7,10]$. A recent review elucidates that good cardiorespiratory fitness mitigates 
stroke hazard in both sexes, and the effect is comparable to well-established stroke risk factors such as blood pressure, obesity, and smoking $[4,11]$. Muscular strength is a commonly accepted parameter for cardiometabolic risk, sarcopenia, functional disabilities, and frailty connected to all-cause mortality [12-14].

$\mathrm{PF}$ is also related to mental health. Previous studies have observed an association between the PF component and cognitive development $[8,9,15]$. Evidence supports that reduced cardiorespiratory fitness and muscular strength are linked to lower levels of mental well-being, higher levels of depressive symptoms and stress-related exhaustion, and increased health-risk behavior such as suicidal attempts [9]. Silverman and Deuster have proposed two possible mechanisms to explain how PF can buffer against stressrelated diseases. The first one is the "blunting effects" of PF on stress responses from the hypothalamic-pituitary-adrenal axis or the sympathetic nervous system. The other one is that improving PF may minimize excessive systemic inflammation. Moreover, PF enhances the neural plasticity and the expression of growth factor, and therefore improves an individual's mood and cognition [16].

Similar observations have been reported among children. Children with suboptimal $\mathrm{PF}$ are at higher risk of pediatric obesity, type 2 diabetes, hypercholesterolemia, hypertension, metabolic syndrome, and cardiovascular diseases [17-19]. Poor childhood PF is linked to increased all-cause mortality in adulthood $[5,20]$. A low level of PF is associated with excessive inflammatory cytokine production [21], with promoting adipose tissue aggregate [22], disrupting platelet function [23], and increasing insulin resistance [24,25]. Moreover, one cross-sectional study suggests that PF plays a crucial role and may ameliorate the negative influence of obesity on children's academic performance $[15,26]$.

Notably, the effects of PF on health outcomes are independent of weight status. Individuals with poor PF, even normal-weighted, have higher mortality than individuals with optimal PF status [27]. Obesity (defined with anthropometric measures), suboptimal body composition (BC), and poor PF have various comorbidities in common, such as metabolic alterations, cardiovascular risks, and mental-cognitive impairment. However, most studies have focused on the medical impacts of each of the three, and the relationships between anthropometry, BC, and PF have not been studied as extensively. Mendoza-Muñoz et al. investigated the influence of $\mathrm{BC}$ on $\mathrm{PF}$ in adolescents and reported that overweight and obese adolescents had lower levels of PF performance [28]. Ortega, F.B., et al. and Hussey, J., et al. demonstrated that cardiorespiratory fitness was negatively correlated with body mass index (BMI), waist circumference and abdominal adiposity in children [5,29]. However, connections between anthropometric measures, BC, and PF in school-aged children had not yet been studied and elucidated thoroughly.

We hypothesized that not only anthropometry but also BC was associated with PF performance among children. The aim of this study was to investigate the associations between body mass index (BMI) z-score, waist/height ratio (WHtR), body-fat percentage (BF\%), muscle weight (MW), 800-m run, sit-and-reach, 1-min sit-ups, and standing long jump in a sample of elementary students in Taiwan.

\section{Materials and Methods}

\subsection{Study Design and Subjects}

The study was quantitative and cross-sectional. Data were collected between 2013 and 2016 from a school-based health promotion project conducted by the Chang Gung Memorial Hospital, Linkou Main Branch, Taoyuan, Taiwan for several elementary schools in Northern Taiwan. The details of the project have been reported elsewhere [30]. Anonymous data was retrieved and analyzed in 2020. All sensitive pieces of information that could be linked to a specific person were deidentified. Demographic data (age, sex), anthropometric measures (BMI z-score, WHtR), BC measures (BF, MW), and PF outcomes (cardiorespiratory fitness (800-m run), flexibility (sit-and-reach), speed/agility (1-min sit-ups), lower body power (long-jump)) were analyzed. This study was approved by the Institutional Review Board 
of our hospital (101-4158A3). Written informed consent was obtained from all participants and their parents.

\subsection{Anthropometric Measures}

Anthropometric measures were obtained collaboratively by school teachers, nurses, and investigators in elementary schools. Each student was asked to take off his or her shoes before body height and weight were measured according to standard protocols [31]. Body height was assessed to the nearest $0.1 \mathrm{~cm}$ by using a wall-mounted stadiometer with head held in horizontal plane [32]. Body weight was measured to the nearest $0.1 \mathrm{~kg}$ by using a metric balance scale [33]. BMI was calculated by dividing the weight $(\mathrm{kg})$ by the height squared $\left(\mathrm{m}^{2}\right)$ [31]. To make weight status comparable across children at different ages, BMI z-scores were calculated based on sex and age in months according to the United States Centers for Disease Control and Prevention 2000 growth charts [34]. Waist circumference $(\mathrm{cm})$ was measured as the circumference in the horizontal plane midway between the lowest ribs and the iliac crest, and it was further divided by the height $(\mathrm{cm})$ to calculate WHtR $[35,36]$.

\subsection{Body Composition Parameters}

The detailed BC measurement protocol has been described elsewhere [30]. Briefly, $\mathrm{BF} \%$ and MW were automatically obtained using bioelectrical impedance analysis (Xscan model, Jawon Medical, Co., Ltd., Seoul, Korea). This segmental multi-frequency bioelectrical impedance analysis module can estimate not only fat-free mass/fat mass but also muscle weight, intracellular water weight and extracellular water weight across limbs and trunks [37]. We chose MW rather than fat-free mass as our parameter of interest since fat-free mass is more complex in its components, including not only muscles but also bone mineral, extracellular water, intracellular water, and visceral protein [37]. Jensen, B., et al. indicated that skeletal muscle mass accounted for $45 \%$ to $49 \%$ of fat-free mass across different sexes [38].

\subsection{Physical Fitness Levels}

PF levels were measured by four exercise tests, including 800-m run, sit-and-reach, 1-min sit-ups, and standing long jump. Cardiorespiratory fitness (endurance run) was assessed by $800-\mathrm{m}$ run $(\mathrm{sec})$, defined as the time required to sprint $800-\mathrm{m}$ run $[39,40]$. Flexibility was evaluated using sit-and-reach $(\mathrm{cm})$, defined by the maximum distance between fingertips and feet reached as the participants slide their hands forward as far as possible towards their feet without bending the hamstring, and maintain this maximum position for at least two seconds [41]. Speed/agility was measured by 1-min sit-ups (times), defined as the maximum number of correct sit-ups achieved in one minute [42]. Lower body power was evaluated using standing long jump, defined as the distance between the starting line and the heel of the closest foot [43]. All PF tests were performed following the methods reported by the Health Promotion Administration, Ministry of Health and Welfare in Taiwan. Standard and corrected stopwatches were used to measure time. Professional physical educators were enrolled to conduct the tests and document the results [44].

\subsection{Statistical Analysis}

The sample size was calculated using a priori calculation (correlation test, coefficient of determination $\rho 2=0.11$, two-tailed $\alpha=0.05$, power $=0.85$; sample size for each age-sex subgroup $=60$ ), as reported in a previous study of $\mathrm{BF} \%$ and standing long jump in 9-yearold boys [43]. For boys and girls aged 9-11 years old (six age-sex subgroups), the sample size was estimated to be 360 .

Most of the distributions of the variables were non-normal, assessed by using the Kolmogorov-Smirnov test. Therefore, non-normally distributed continuous variables were transformed using a two-step approach: the fractional rank and inverse-normal transformation [45]. Thereafter, continuous variables were expressed as means and stan- 
dard deviations, and categorical variables were expressed as numbers with percentages. Student $t$-tests were used to compare continuous variables, and chi-square tests were used to compare categorical variables in different subgroups, as appropriate. Pearson's correlation test was used to investigate the relationships between continuous variables, whereas Spearman's correlation test was used to analyze associations between continuous variables and categorical variables. The variables with a significance level of $p<0.05$ in univariate analyses were further assessed using multivariable linear regression models with the forward selection for examining independent variables.

SPSS software (version 25; International Business Machines Corp., Armonk, NY, USA) and $\mathrm{G}^{*}$ Power software (version 3.1.9.2; University of Kiel, Kiel, Germany) were used for the statistical analysis. A two-tailed $p$-value lower than 0.05 was considered statistically significant.

\section{Results}

\subsection{Demographic and Clinical Characteristics of the Overall Cohort and Two Subgroups Stratified by Sex}

Table 1 displayed demographic and clinical characteristics of the overall cohort and two subgroups stratifies by sex. A total of 360 Taiwanese children from Han ancestry (180 (50.0\%) girls and $180(50.0 \%)$ boys); mean age: $10.0 \pm 0.7$ years; mean BMI z-score: $0.366 \pm 1.216)$ were analyzed.

Table 1. Participant characteristics of the overall cohort as well as two subgroups stratified by sex.

\begin{tabular}{|c|c|c|c|c|}
\hline Variables & Overall & Boys & Girls & $p$-Value ${ }^{\mathrm{a}}$ \\
\hline Participants & $n=360$ & $n=180$ & $n=180$ & \\
\hline \multicolumn{5}{|c|}{ Demographic measures } \\
\hline Age (years) & $10.0 \pm 0.6$ & $10.0 \pm 0.7$ & $10.0 \pm 0.6$ & 0.72 \\
\hline \multicolumn{5}{|c|}{ Anthropometric measures } \\
\hline Body mass index z-score & $0.366 \pm 1.216$ & $0.543 \pm 1.269$ & $0.190 \pm 1.137$ & 0.01 \\
\hline Waist/height ratio & $0.46 \pm 0.06$ & $0.47 \pm 0.06$ & $0.45 \pm 0.06$ & $<0.001$ \\
\hline \multicolumn{5}{|c|}{ Body composition measures } \\
\hline Body-fat percentage & $16.9 \pm 7.6$ & $14.1 \pm 8.0$ & $19.5 \pm 6.1$ & $<0.001$ \\
\hline Muscle weight (kg) & $29.0 \pm 6.1$ & $30.7 \pm 5.6$ & $27.5 \pm 6.2$ & $<0.001$ \\
\hline \multicolumn{5}{|c|}{ Physical fitness levels } \\
\hline $800-\mathrm{m}$ run (sec) & $306.9 \pm 69.4$ & $297.1 \pm 74.2$ & $316.7 \pm 63.0$ & 0.01 \\
\hline Sit-and-reach $(\mathrm{cm})$ & $25.6 \pm 8.4$ & $23.1 \pm 8.1$ & $28.1 \pm 7.9$ & $<0.001$ \\
\hline 1-min sit-ups (time) & $27.8 \pm 8.8$ & $28.7 \pm 9.6$ & $26.9 \pm 7.9$ & 0.049 \\
\hline Standing long jump $(\mathrm{cm})$ & $137.1 \pm 25.6$ & $141.1 \pm 27.0$ & $133.1 \pm 23.5$ & 0.003 \\
\hline
\end{tabular}

Data are summarized as means \pm standard deviations. ${ }^{a}$ Data were compared using the Student $t$-test.

In the overall cohort, the boys had a significantly higher BMI z-score, higher WHtR, lower $\mathrm{BF} \%$, higher $\mathrm{MW}$, lower time in the 800-m run, lower distance of sit-and-reach, higher number of 1-min sit-ups, and higher distance of standing long jump compared to those of the girls. The boys and girls were comparable in age.

\subsection{Associations of Physical Fitness Levels and Variables of Interest in the Overall Cohort}

Table 2 displayed associations of PF and variables of interest in the overall cohort. The 800-m run was positively associated with female sex, BMI z-score, WHtR, BF\%, and MW. Sit-and-reach was positively correlated with female sex and age, and inversely related to BMI z-score and WHtR. The 1-min sit-ups score was positively related to age and inversely associated with BMI z-score, $\mathrm{WHtR}$, and $\mathrm{BF} \%$. Standing long jump was positively associated with age and MW, and inversely correlated with female sex, $\mathrm{WHtR}$, and $\mathrm{BF} \%$. 
3.3. Variables Independently Associated with Physical Fitness Levels in the Overall Cohort Using Logistic Regression Models

Table 3 displayed variables independently associated with PF in the overall cohort. Using univariate linear regression models, we determined that girls, BMI z-score, $\mathrm{WHtR}$, $\mathrm{BF} \%$, and MW were significant variables of the $800-\mathrm{m}$ run. However, only the $\mathrm{BF} \%$ (regression coefficient $(\mathrm{B})=3.4,95 \%$ confidence interval $(\mathrm{CI})=2.5-4.3, p<0.001$ ) was independently correlated with the 800-m run using multivariable linear regression models.

Female sex, age, BMI z-score, and WHtR were significant variables of sit-and-reach. Using multivariable analysis, girls $(B=4.6,95 \% C I=3.0-6.3, p<0.001)$, age $(B=3.1,95 \%$ $\mathrm{CI}=1.9-4.3, p<0.001)$, and BMI z-score $(\mathrm{B}=-0.7,95 \% \mathrm{CI}=-1.4--0.1, p=0.03)$ were still significantly and independently related to the sit-and-reach.

Female sex, age, BMI z-score, WHtR, and $\mathrm{BF} \%$ were significant factors of 1-min situps. Furthermore, age $(\mathrm{B}=3.3,95 \% \mathrm{CI}=2.0-4.7, p<0.001)$ and $\mathrm{BF} \%(\mathrm{~B}=-0.3,95 \%$ $\mathrm{CI}=-0.4-0.2, p<0.001)$ were still significant variables of 1-min sit-and-stand-ups using multivariable analysis.

Female sex, age, WHtR, BF\%, and MW were significant factors of the standing long jump. Their associations with the standing long jump remained significant using multivariable analysis: age $(\mathrm{B}=14.1,95 \% \mathrm{CI}=9.9-18.3, p<0.001), \mathrm{BF} \%(\mathrm{~B}=-1.1,95 \% \mathrm{CI}=-1.4-1.2$, $p<0.001)$, and $\mathrm{MW}(\mathrm{B}=0.7,95 \% \mathrm{CI}=0.2-1.2, p=0.01)$. 
Table 2. Associations ${ }^{a}$ of dichotomized variables of interest.

\begin{tabular}{|c|c|c|c|c|c|c|c|c|c|c|}
\hline Predictors & Female Sex ${ }^{a}$ & Age $^{b}$ & $\begin{array}{c}\text { Body Mass } \\
\text { Index z-Score }\end{array}$ & $\begin{array}{c}\text { Waist/Height } \\
\text { Ratio }^{\text {b }}\end{array}$ & $\begin{array}{c}\text { Body-Fat } \\
\text { Percentage }\end{array}$ & Muscle Weight ${ }^{\text {b }}$ & 800-m Run ${ }^{b}$ & Sit-and-Reach ${ }^{b}$ & 1-min Sit-Ups ${ }^{b}$ & $\begin{array}{c}\text { Standing Long } \\
\text { Jump }^{\mathrm{b}}\end{array}$ \\
\hline Female sex & - & & & & & & & & & \\
\hline Age & $0.02(0.72)$ & - & & & & & & & & \\
\hline $\begin{array}{l}\text { Body mass } \\
\text { index z-score }\end{array}$ & $-0.14(0.01 *)$ & $-0.03(0.63)$ & - & & & & & & & \\
\hline $\begin{array}{l}\text { Waist/height } \\
\text { ratio }\end{array}$ & $-0.19(<0.001 *)$ & $-0.05(0.37)$ & $0.80(<0.001 *)$ & - & & & & & & \\
\hline $\begin{array}{l}\text { Body-fat } \\
\text { percentage }\end{array}$ & $0.36\left(<0.001^{*}\right)$ & $0.03(0.57)$ & $0.69(<0.001 *)$ & $0.62(<0.001 *)$ & - & & & & & \\
\hline Muscle weight & $-0.24(<0.001 *)$ & $0.44(<0.001 *)$ & $0.68(<0.001 *)$ & $0.43(<0.001 *)$ & $0.43(<0.001 *)$ & - & & & & \\
\hline 800-m run & $0.15(0.004 *)$ & $-0.04(0.42)$ & $0.28(<0.001 *)$ & $0.27(<0.001 *)$ & $0.37(<0.001 *)$ & $0.11(0.04 *)$ & - & & & \\
\hline Sit-and-reach & $0.32\left(<0.001^{*}\right)$ & $0.26\left(<0.001^{*}\right)$ & $-0.15(0.004 *)$ & $-0.15(0.01 *)$ & $0.02(0.69)$ & $-0.07(0.22)$ & $-0.04(0.51)$ & - & & \\
\hline 1-min sit-ups & $-0.10(0.06)$ & $0.22\left(<0.001^{*}\right)$ & $-0.14\left(0.01^{*}\right)^{\prime}$ & $-0.18\left(<0.001^{*}\right)$ & $-0.28\left(<0.001^{*}\right)$ & $0.01(0.92)$ & $-0.48(<0.001 *)$ & $0.08(0.11)$ & - & \\
\hline $\begin{array}{l}\text { Standing long } \\
\text { jump }\end{array}$ & $-0.15\left(0.004^{*}\right)$ & $0.42(<0.001 *)$ & $-0.10(0.06)$ & $-0.11\left(0.04^{*}\right)$ & $-0.24\left(<0.001^{*}\right)$ & $0.18(0.001 *)$ & $-0.39(<0.001 *)$ & $0.27(<0.001 *)$ & $0.44(<0.001 *)$ & - \\
\hline
\end{tabular}

Data are summarized as Spearman correlation coefficients ( $p$-values). ${ }^{\text {a }}$ Data were analyzed using the Spearman correlation test. ${ }^{\mathrm{b}}$ Data were analyzed using the Pearson correlation test. ${ }^{*} p$-value $<0.05$. 
Table 3. Univariate and multivariable regression models of physical fitness levels in the overall cohort.

\begin{tabular}{|c|c|c|c|c|}
\hline Predictors & B $(95 \% C I)$ & $p$-Value ${ }^{\text {a }}$ & B $(95 \% C I)$ & $p$-Value ${ }^{\mathrm{a}}$ \\
\hline & \multicolumn{2}{|c|}{ Univariate Model } & \multicolumn{2}{|c|}{ Multivariate Model } \\
\hline \multicolumn{5}{|c|}{ 800-m run } \\
\hline Female sex & $19.6(5.3-33.9)$ & 0.01 & & NS \\
\hline Age & $-4.5(-15.5-6.5)$ & 0.42 & & NI \\
\hline Body mass index z-score & $15.9(10.2-21.6)$ & $<0.001$ & & NS \\
\hline Waist/height ratio & $290.5(180.7-400.2)$ & $<0.001$ & & NS \\
\hline Body-fat percentage & $3.3(2.4-4.2)$ & $<0.001$ & $3.4(2.5-4.3)$ & $<0.001$ \\
\hline Muscle weight & $1.3(0.1-2.5)$ & 0.04 & & NS \\
\hline \multicolumn{5}{|c|}{ Sit-and-reach } \\
\hline Female sex & $5.0(3.4-6.7)$ & $<0.001$ & $4.6(3.0-6.3)$ & $<0.001$ \\
\hline Age & $3.3(2.0-4.6)$ & $<0.001$ & $3.1(1.9-4.3)$ & $<0.001$ \\
\hline Body mass index z-score & $-1.1(-1.8--0.3)$ & 0.004 & $-0.7(-1.4--0.1)$ & 0.03 \\
\hline Waist/height ratio & $-19.0(-32.5--5.5)$ & 0.01 & & NS \\
\hline Body-fat percentage & $0.02(-0.10-0.14)$ & 0.69 & & NI \\
\hline Muscle weight & $-0.1(-0.2-0.1)$ & 0.22 & & NI \\
\hline \multicolumn{5}{|c|}{ 1-min sit-ups } \\
\hline Female sex & $-1.8(-3.7--0.1)$ & 0.049 & & NS \\
\hline Age & $2.9(1.6-4.3)$ & $<0.001$ & $3.3(2.0-4.7)$ & $<0.001$ \\
\hline Body mass index z-score & $-1.0(-1.8--0.3)$ & 0.01 & & NS \\
\hline Waist/height ratio & $-24.8(-38.9--10.7)$ & 0.001 & & NS \\
\hline Body-fat percentage & $-0.3(-0.4--0.2)$ & $<0.001$ & $-0.3(-0.4--0.2)$ & $<0.001$ \\
\hline Muscle weight & $0.1(-0.1-0.2)$ & 0.92 & & NI \\
\hline \multicolumn{5}{|c|}{ Standing long jump } \\
\hline Female sex & $-8.0(-13.2--2.7)$ & 0.003 & & NS \\
\hline Age & $16.3(12.6-20.0)$ & $<0.001$ & $14.1(9.9-18.3)$ & $<0.001$ \\
\hline Body mass index z-score & $-2.1(-4.3-0.1)$ & 0.06 & & NS \\
\hline Waist/height ratio & $-42.5(-83.8--1.1)$ & 0.04 & & NS \\
\hline Body-fat percentage & $-0.8(-1.2--0.5)$ & $<0.001$ & $-1.1(-1.4--0.7)$ & $<0.001$ \\
\hline Muscle weight & $0.8(0.3-1.2)$ & 0.001 & $0.7(0.2-1.2)$ & 0.01 \\
\hline
\end{tabular}

Abbreviations: B: regression coefficient; CI: confidence interval; NI: not included; NS: not significant. ${ }^{\text {a }}$ Data were compared using linear regression models.

\section{Discussion}

The prevalence of pediatric obesity has been increasing alarmingly worldwide in the past 20 years [46-48]. It is generally believed that a decrease in PA and excessive calorie consumption are the two most important factors responsible for this obesity pandemic [49,50]. The detrimental effects of obesity can result in a wide range of negative impacts on health and quality of life [51]. The literature has elucidated various comorbidities of pediatric obesity, including early sexual maturation, polycystic ovary syndrome, nonalcoholic fatty liver disease, obstructive sleep apnea, asthma, left ventricular hypertrophy, hypertension, lower extremity malalignment and joint pain, acanthosis nigricans, higher risk of idiopathic intracranial hypertension, poor self-esteem, anxiety, and depression [51].

On the other hand, a decrease in PF performance has been observed in many developing and developed countries [50]. Young populations are becoming more obese and less fit at the same time, and some research has suggested a linkage between the changes in PF and weight status $[50,52,53]$. Overweight and obese adolescents had inferior PF compared to their normal-weight peers [28]. Children with higher cardiorespiratory fitness had less total and abdominal adiposity $[5,28]$. Tomkinson et al. demonstrated that the variability in fatness was accounted for about $20 \%$ of the variability in running performance [54]. A 
cross-sectional study also showed that fatness attributed to the decline of PF by $29-61 \%$, more than other factors such as PA did [52].

In our results, and consistent with the literature, the PF performance of children was associated with their demographic variables [55]. Older children had better flexibility, speed/agility, and lower body power. Children grow up with their height, weight, lean mass, fat tissue, and organs increasing in size [56,57]. These changes are the results of cellular hyperplasia, hypertrophy, and intercellular accretion, enhancing the functional utility of skeletal muscles [58]. Moreover, children develop better motor performance with a better integration of their central nervous system and skeletal-muscular system [59]. Previous investigations report that older age is associated with higher running speed from increased stride length, frequency, and neuromuscular coordination [60,61].

Interesting sex differences were observed. Boys were higher in z-BMI and WHtR, consistent with the well-documented higher prevalence of overweight and obesity in boys in Taiwan [62,63]. Girls were higher in BF\% and lower in MW, also consistent with the literature $[64,65]$. After adjusting for other confounders, girls were better with flexibility. Previous studies show that girls have more total and subcutaneous fat, more connective tissue, and less paraspinous musculature compared to boys $[64,66]$. This difference could be explained by the difference in sex hormone levels between prepubertal children [67]. Boys have a greater capacity of skeletal muscle because of a higher level of testosterone [57,58]. In comparison, girls have a higher $\mathrm{BF} \%$ and lower percentage of muscle mass because of a higher amount of estrogen, which contributes to lower tissue density and better flexibility [66]. The divergence of sexual hormone level and BC causes distinct flexibility performance between different sexes [68,69].

As expected and consistent with some previous research [29,70,71], our data demonstrated connections between weight status, BC, and PF. In general, higher BMI-z score and $\mathrm{BF} \%$ were linked with lower levels of $\mathrm{PF}$.

First, higher z-BMI was associated with worse flexibility. Larger trunk mass increased mechanical work and moment of inertia. As a result, there was higher propulsion and extra load during dynamic activities [70]. Casonatto et al. indicated that abdominal obesity might affect the lower back and hamstring flexibility and hamper the trunk to the extreme reach position [72].

Second, excessive $\mathrm{BF} \%$ was related to poorer muscle endurance, cardiorespiratory fitness, and lower-body power. Similar findings have been reported by other investigators [28,73-75]. One systematic review from the European Childhood Obesity Group suggests that insulin resistance causes mitochondrial dysfunction in the skeletal muscle, which leads to muscle fatigability and delayed post-effort muscle recovery [76]. Another systematic review shows the negative effects of childhood obesity on spirometric variables, namely reductions in forced expiratory volume in one second, forced vital capacity, and forced expiratory volume in one second/forced vital capacity ratio $[77,78]$. An increase in adipose tissue directly negatively impacts one's pulmonary function by reducing functional residual capacity, expiratory reserve volume, and residual volume [79,80]. Previous studies have reported that children with obesity perform less well in weight-bearing activities such as jumping and running $[53,75,81]$. Children with higher BMI usually have higher muscle mass, which increases absolute muscle strength; however, relative muscle strength is the key component of muscle function for daily activities. Excessive BF\% increases inert load, which impacts negatively on relative muscle strength and results in poorer lower-body power [75].

Third, children with higher muscle weight had better lower-body power. There are two types of skeletal muscle, type I (red fibers) and type II (white fibers). Type II fibers have higher force, power, and speed. Most one-burst moves, such as the long jump or badminton smash, are largely contributed by type II fibers due to their higher contractility and fast reactions. On the other hand, type I fibers are slow movers but have better ability in utilizing oxygen and higher endurance [82]. Gaining muscle weight is largely related to type II fiber rather than type I fibers [83]. Our results were consistent with the physiology, 
showing that muscle weight was significant in relation to lower-body explosive power, but not muscle endurance.

The main contribution of this study was to provide scientific evidence on how anthropometry and BC may affect the PF performance, in addition to age and sex. The study had some limitations. First, all the participants were Han and confined to age of 9-11 years, which might limit the generalizability of this study to other populations. Second, the information on pubertal status was not collected, which might have been an important confounder on weight status, BC, and PF. Third, BC was measured by BIA; BIA modules are less costly and more available, but less accurate than dual energy $\mathrm{X}$-ray absorptiometry modules. Also, the study was cross-sectional and therefore unable to conduct causation in predicting the future performance. Further studies with a prospective design will be of interest.

\section{Conclusions}

Overall, younger age, higher BMI z-score, and higher BF\% were associated with poorer PF performance among elementary school students; girls had better flexibility. Our study concluded that other than demographic variables, anthropometric measures and BC parameters provided additional information in concerning PF levels in school-aged children. PF testing should be considered in addition to clinical measures to understand children's health more comprehensively. Health promotion for children should focus not only on anthropometry but also BC and PF.

Author Contributions: Conceptualization, S.W.-N.U. and H.-H.C.; methodology, S.-W.H. and R.H.L.; software, S.-W.H. and R.-H.L.; validation, L.-S.C., I.-J.C. and W.-C.F; formal analysis, H.-H.C.; investigation, C.-Y.H. and H.-H.C.; resources, L.-S.C., I.-J.C., W.-C.F. and H.-H.C.; data curation, S.-W.H. and R.-H.L.; writing - original draft preparation, C.-Y.H., L.-S.C. and H.-H.C.; writingreview and editing, L.-S.C., I.-J.C. and H.-H.C.; visualization, S.-W.H. and R.-H.L.; supervision, S.W.-N.U.; project administration, S.W.-N.U. and H.-H.C.; funding acquisition, S.W.-N.U. and H.-H.C. All authors have read and agreed to the published version of the manuscript.

Funding: The study was funded by Chang Gung Medical Foundation, Grant number: CMRPG1H0061, CMRPG1H0062, CMRPG1H0063, CMRPG1J041, CMRPG1J042 (H.-H.C.).

Institutional Review Board Statement: The study was conducted according to the guidelines of the Declaration of Helsinki and approved by the Institutional Review Board of Chang Gung Memorial Hospital, Linkou (101-4158A3).

Informed Consent Statement: Informed consent was obtained from all patients involved in the study.

Data Availability Statement: Data available on request due to privacy/ethical restrictions.

Acknowledgments: The authors would like to thank Pei-Chi Yang, Yu-Chan Liao, and Yi-Ting Lin, Chang Gung Memorial Hospital, Linkou and Taipei Branches, Taoyuan, Taiwan, for their help in the data collection, analysis, and manuscript editing. The authors would also like to express our respects and appreciations for Kuang-Hung Hsu from Chang Gung University, Taoyuan, Taiwan for his great help and support for the project.

Conflicts of Interest: The authors declare no conflict of interest.

\section{References}

1. Corbin, C.B.; Lindsey, R. Concepts of Physical Fitness; McGraw-Hill Education: New York, NY, USA, 1997.

2. Pate, R.R. The Evolving Definition of Physical Fitness. Quest 1988, 40, 174-179. [CrossRef]

3. Lin, Y.-T.; Lee, P.-F.; Lee, T.-S.; Ho, C.-C. Poor Physical Fitness Performance as a Predictor of General Adiposity in Taiwanese Adults. Int. J. Environ. Res. Public Health 2020, 17, 2686. [CrossRef]

4. Booth, F.W.; Roberts, C.K.; Laye, M. Lack of Exercise Is a Major Cause of Chronic Diseases. Compr. Physiol. $2012,2,1143-1211$. [CrossRef]

5. Ortega, F.B.; Ruiz, J.; Castillo, M.J.; Sjöström, M. Physical fitness in childhood and adolescence: A powerful marker of health. Int. J. Obes. 2007, 32, 1-11. [CrossRef]

6. Henriques-Neto, D.; Magalhães, J.P.; Hetherington-Rauth, M.; Santos, D.A.; Baptista, F.; Sardinha, L. Physical Fitness and Bone Health in Young Athletes and Nonathletes. Sports Health 2020, 12, 441-448. [CrossRef] [PubMed] 
7. Mäestu, E.; Harro, J.; Veidebaum, T.; Kurrikoff, T.; Jürimäe, J.; Mäestu, J. Changes in cardiorespiratory fitness through adolescence predict metabolic syndrome in young adults. Nutr. Metab. Cardiovasc. Dis. 2020, 30, 701-708. [CrossRef]

8. Åvitsland, A.; Leibinger, E.; Haugen, T.; Lerum, Ø.; Solberg, R.B.; Kolle, E.; Dyrstad, S.M. The association between physical fitness and mental health in Norwegian adolescents. BMC Public Health 2020, 20, 776. [CrossRef] [PubMed]

9. Appelqvist-Schmidlechner, K.; Vaara, J.P.; Vasankari, T.; Häkkinen, A.; Mäntysaari, M.; Kyröläinen, H. Muscular and cardiorespiratory fitness are associated with health-related quality of life among young adult men. BMC Public Health 2020, $20,842$. [CrossRef] [PubMed]

10. Kim, B.; Ku, M.; Kiyoji, T.; Isobe, T.; Sakae, T.; Oh, S. Cardiorespiratory fitness is strongly linked to metabolic syndrome among physical fitness components: A retrospective cross-sectional study. J. Physiol. Anthr. 2020, 39, 1-9. [CrossRef] [PubMed]

11. Wang, Y.; Li, F.; Cheng, Y.; Gu, L.; Xie, Z. Cardiorespiratory fitness as a quantitative predictor of the risk of stroke: A dose-response meta-analysis. J. Neurol. 2020, 267, 491-501. [CrossRef]

12. García-Hermoso, A.; Cavero-Redondo, I.; Ramírez-Vélez, R.; Ruiz, J.R.; Ortega, F.B.; Lee, D.-C.; Martínez-Vizcaíno, V. Muscular Strength as a Predictor of All-Cause Mortality in an Apparently Healthy Population: A Systematic Review and Meta-Analysis of Data from Approximately 2 Million Men and Women. Arch. Phys. Med. Rehabil. 2018, 99, 2100-2113. [CrossRef]

13. Lee, S.H.; Gong, H.S. Measurement and Interpretation of Handgrip Strength for Research on Sarcopenia and Osteoporosis. J. Bone Metab. 2020, 27, 85-96. [CrossRef] [PubMed]

14. Zaccagni, L.; Toselli, S.; Bramanti, B.; Gualdi-Russo, E.; Mongillo, J.; Rinaldo, N. Handgrip Strength in Young Adults: Association with Anthropometric Variables and Laterality. Int. J. Environ. Res. Public Health 2020, 17, 4273. [CrossRef]

15. Moradi, A.; Damirchi, E.S.; Narimani, M.; Esmaeilzadeh, S.; Dziembowska, I.; Azevedo, L.B.; Prado, W.L.D. Association between Physical and Motor Fitness with Cognition in Children. Medicina 2019, 55, 7. [CrossRef]

16. Silverman, M.N.; Deuster, P.A. Biological mechanisms underlying the role of physical fitness in health and resilience. Interface Focus 2014, 4, 20140040. [CrossRef] [PubMed]

17. Dwyer, T.; Magnussen, C.G.; Schmidt, M.D.; Ukoumunne, O.C.; Ponsonby, A.-L.; Raitakari, O.T.; Zimmet, P.Z.; Blair, S.N.; Thomson, R.; Cleland, V.; et al. Decline in Physical Fitness from Childhood to Adulthood Associated with Increased Obesity and Insulin Resistance in Adults. Diabetes Care 2008, 32, 683-687. [CrossRef]

18. García-Hermoso, A.; Alonso-Martinez, A.M.; Ramírez-Vélez, R.; Izquierdo, M. Effects of Exercise Intervention on Health-Related Physical Fitness and Blood Pressure in Preschool Children: A Systematic Review and Meta-Analysis of Randomized Controlled Trials. Sports Med. 2020, 50, 187-203. [CrossRef] [PubMed]

19. Pazzianotto-Forti, E.M.; Moreno, M.A.; Plater, E.; Baruki, S.B.S.; Junior, I.R.; Reid, W.D. Impact of Physical Training Programs on Physical Fitness in People with Class II and III Obesity: A Systematic Review and Meta-Analysis. Phys. Ther. 2020, 100, 963-978. [CrossRef] [PubMed]

20. Sato, M.; Kodama, S.; Sugawara, A.; Saito, K.; Sone, H. Physical Fitness During Adolescence and Adult Mortality. Epidemiology 2009, 20, 463-464. [CrossRef]

21. Sacheck, J. Pediatric Obesity: An Inflammatory Condition? J. Parenter. Enter. Nutr. 2008, 32, 633-637. [CrossRef] [PubMed]

22. Dumuid, D.; Olds, T.; Lewis, L.K.; Martin-Fernández, J.A.; Barreira, T.; Broyles, S.; Chaput, J.-P.; Fogelholm, M.; Hu, G.; Kuriyan, R.; et al. The adiposity of children is associated with their lifestyle behaviours: A cluster analysis of school-aged children from 12 nations. Pediatr. Obes. 2018, 13, 111-119. [CrossRef] [PubMed]

23. Buchan, D.S.; Thomas, N.E.; Baker, J.S. Novel risk factors of cardiovascular disease and their associations between obesity, physical activity and physical fitness. J. Public Health Res. 2012, 1, 11-66. [CrossRef] [PubMed]

24. Schmitz, K.; Jacobs, D.R.; Hong, C.-P.; Steinberger, J.; Moran, A.; Sinaiko, A. Association of physical activity with insulin sensitivity in children. Int. J. Obes. 2002, 26, 1310-1316. [CrossRef]

25. Chae, H.-W.; Kwon, Y.-N.; Rhie, Y.-J.; Kim, H.-S.; Kim, Y.-S.; Paik, I.-Y.; Suh, S.-H.; Kim, D.-H. Effects of a Structured Exercise Program on Insulin Resistance, Inflammatory Markers and Physical Fitness in Obese Korean Children. J. Pediatr. Endocrinol. Metab. 2010, 23, 1065-1072. [CrossRef]

26. Muntaner-Mas, A.; Palou, P.; Vidal-Conti, J.; Esteban-Cornejo, I. A Mediation Analysis on the Relationship of Physical Fitness Components, Obesity, and Academic Performance in Children. J. Pediatr. 2018, 198, 90-97. [CrossRef]

27. Barry, V.W.; Baruth, M.; Beets, M.W.; Durstine, J.L.; Liu, J.; Blair, S.N. Fitness vs. Fatness on All-Cause Mortality: A Meta-Analysis. Prog. Cardiovasc. Dis. 2014, 56, 382-390. [CrossRef] [PubMed]

28. Mendoza-Muñoz, M.; Adsuar, J.; Pérez-Gómez, J.; Muñoz-Bermejo, L.; Garcia-Gordillo, M.; Carlos-Vivas, J. Influence of Body Composition on Physical Fitness in Adolescents. Medicina 2020, 56, 328. [CrossRef] [PubMed]

29. Hussey, J.; Bell, C.; Bennett, K.; O’Dwyer, J.; Gormley, J. Relationship between the intensity of physical activity, inactivity, cardiorespiratory fitness and body composition in 7-10-year-old Dublin children. Br. J. Sports Med. 2007, 41, 311-316. [CrossRef]

30. Chuang, H.-H.; Lin, R.-H.; Chen, J.-Y.; Yeh, W.-C.; Lin, H.-F.; Ueng, S.W.-N.; Hsu, K.-H. Effectiveness of a multi-faceted intervention among elementary school children. Medicina 2019, 98, e15079. [CrossRef] [PubMed]

31. Sekgala, M.D.; Monyeki, K.D.; Mogale, M.A.; Ramoshaba, N.E. Performance of blood pressure to height ratio as a screening tool for elevated blood pressure in rural children: Ellisras Longitudinal Study. J. Hum. Hypertens. 2017, 31, 591-595. [CrossRef]

32. Nafiu, O.O.; Burke, C.; Lee, J.; Voepel-Lewis, T.; Malviya, S.; Tremper, K.K. Neck Circumference as a Screening Measure for Identifying Children with High Body Mass Index. Pediatrics 2010, 126, e306-e310. [CrossRef] 
33. Chung, K.; Chiou, H.; Chang, J.; Chen, Y. Associations of nitric oxide with obesity and psychological traits among children and adolescents in Taiwan. Pediatr. Obes. 2019, 15, e12593. [CrossRef]

34. Flegal, K.M.; Cole, T.J. Construction of LMS parameters for the Centers for Disease Control and Prevention 2000 growth charts. Natl. Health Stat. Rep. 2013, 2013, 1-3.

35. Ma, W.-Y.; Yang, C.-Y.; Shih, S.-R.; Hsieh, H.-J.; Hung, C.S.; Chiu, F.-C.; Lin, M.-S.; Liu, P.-H.; Hua, C.-H.; Hsein, Y.-C.; et al. Measurement of Waist Circumference: Midabdominal or iliac crest? Diabetes Care 2013, 36, 1660-1666. [CrossRef] [PubMed]

36. Lohman, T.G.; Roche, A.F.; Martorell, R. Anthropometric Standardization Reference Manual; Human Kinetics Books: Champaign, IL, USA, 1998.

37. Grossi, M.; Riccò, B. Electrical impedance spectroscopy (EIS) for biological analysis and food characterization: A review. J. Sens. Sens. Syst. 2017, 6, 303-325. [CrossRef]

38. Jensen, B.; Braun, W.; Geisler, C.; Both, M.; Klückmann, K.; Müller, M.J.; Bosy-Westphal, A. Limitations of Fat-Free Mass for the Assessment of Muscle Mass in Obesity. Obes. Facts 2019, 12, 307-315. [CrossRef]

39. Hu, J.; Li, Z.; Li, S.; Li, H.; Wang, S.; Wang, S.; Han, L. Skipping breakfast and physical fitness among school-aged adolescents. Clinics 2020, 75, e1599. [CrossRef]

40. Hsieh, P.-L.; Chen, M.-L.; Huang, C.-M.; Chen, W.-C.; Li, C.-H.; Chang, L.-C. Physical Activity, Body Mass Index, and Cardiorespiratory Fitness among School Children in Taiwan: A Cross-Sectional Study. Int. J. Environ. Res. Public Health 2014, 11, 7275-7285. [CrossRef]

41. Hartman, J.G.; Looney, M. Norm-Referenced and Criterion-Referenced Reliability and Validity of the Back-Saver Sit-and-Reach. Meas. Phys. Educ. Exerc. Sci. 2003, 7, 71-87. [CrossRef]

42. Lovecchio, N.; Novak, D.; Sedlacek, J.; Hamar, P.; Milanovic, I.; Radisavljevic-Janic, S.; Emeljanovas, A.; Eid, L.; Zago, M. Physical fitness for sedentary students: A common trend from six European countries. J. Sports Med. Phys. Fit. 2019, 59, 1389-1396. Available online: https:/ / www.minervamedica.it/index2.php?show=R40Y2019N08A1389 (accessed on 4 May 2020). [CrossRef] [PubMed]

43. Reid, R.E.; Fillon, A.; Thivel, D.; Henderson, M.; Barnett, T.A.; Bigras, J.-L.; Mathieu, M.-E. Can anthropometry and physical fitness testing explain physical activity levels in children and adolescents with obesity? J. Sci. Med. Sport 2020, $23,580-585$. [CrossRef] [PubMed]

44. Ministry of Education. Measures for the Implementation of Physical Fitness Testing in Taiwan. 2018. Available online: https: / / edu.law.moe.gov.tw / LawContent.aspx?id=GL000769 (accessed on 28 March 2021).

45. Templeton, G.F. A Two-Step Approach for Transforming Continuous Variables to Normal: Implications and Recommendations for IS Research. Commun. Assoc. Inf. Syst. 2011, 28, 41-58. [CrossRef]

46. Wang, Y.; Lim, H. The global childhood obesity epidemic and the association between socio-economic status and childhood obesity. Int. Rev. Psychiatry 2012, 24, 176-188. [CrossRef]

47. NCD Risk Factor Collaboration (NCD-RisC). Heterogeneous contributions of change in population distribution of body mass index to change in obesity and underweight. Elife 2021, 10, e60060. [CrossRef] [PubMed]

48. Rodriguez-Martinez, A.; Zhou, B.; Sophiea, M.K.; Bentham, J.; Paciorek, C.J.; Iurilli, M.L.; Carrillo-Larco, R.M.; Bennett, J.E.; Di Cesare, M.; Taddei, C.; et al. Height and body-mass index trajectories of school-aged children and adolescents from 1985 to 2019 in 200 countries and territories: A pooled analysis of 2181 population-based studies with 65 million participants. Lancet 2020, 396, 1511-1524. [CrossRef]

49. Ostojic, S.M.; Stojanovic, M.D.; Stojanovic, V.; Maric, J.; Njaradi, N. Correlation between Fitness and Fatness in 6-14-year Old Serbian School Children. J. Health Popul. Nutr. 2011, 29, 53-60. [CrossRef]

50. Tomkinson, G.R.; Léger, L.A.; Olds, T.S.; Cazorla, G. Secular Trends in the Performance of Children and Adolescents (1980-2000). Sports Med. 2003, 33, 285-300. [CrossRef]

51. Kumar, S.; Kelly, A.S. Review of Childhood Obesity: From Epidemiology, Etiology, and Comorbidities to Clinical Assessment and Treatment. Mayo Clin. Proc. 2017, 92, 251-265. [CrossRef]

52. Olds, T.S.; Ridley, K.; Tomkinson, G.R. Declines in aerobic fitness: Are they only due to increasing fatness? Med. Sport Sci. 2007, 50, 226-240. [PubMed]

53. Sacchetti, R.; Ceciliani, A.; Garulli, A.; Masotti, A.; Poletti, G.; Beltrami, P.; Leoni, E. Physical fitness of primary school children in relation to overweight prevalence and physical activity habits. J. Sports Sci. 2012, 30, 633-640. [CrossRef] [PubMed]

54. Tomkinson, G.R.; Olds, T.S. Secular Changes in Pediatric Aerobic Fitness Test Performance: The Global Picture. Med. Sport Sci. 2007, 50, 46-66.

55. Zaqout, M.; Vyncke, K.; Moreno, L.A.; De Miguel-Etayo, P.; Lauria, F.; Molnar, D.; Lissner, L.; Hunsberger, M.; Veidebaum, T.; Tornaritis, M.; et al. Determinant factors of physical fitness in European children. Int. J. Public Health 2016, 61, 573-582. [CrossRef]

56. Lämmle, L.; Worth, A.; Bös, K. Socio-demographic correlates of physical activity and physical fitness in German children and adolescents. Eur. J. Public Health 2012, 22, 880-884. [CrossRef]

57. Rosa-Guillamón, A.; Carrillo-López, P.J.; García-Cantó, E. Analysis of physical fitness according to sex, age, body mass index and level of physical activity in Spanish elementary school students. Rev. Fac. Med. 2020, 68, 92-99.

58. Malina, R.M.; Bouchard, C. Growth, Maturation, and Physical Activity. Med. Sci. Sports Exerc. 1992, 24, 841. [CrossRef]

59. Haywood, K.M.; Getchell, N. Life Span Motor Development; Human Kinetics: Champaign, IL, USA, 2019. 
60. Milanese, C.; Sandri, M.; Cavedon, V.; Zancanaro, C. The role of age, sex, anthropometry, and body composition as determinants of physical fitness in nonobese children aged 6-12. Peer] 2020, 8, e8657. [CrossRef]

61. Praagh, E.V. Anaerobic fitness tests: What are we measuring? Med. Sport Sci. 2007, 50, $26-45$.

62. Chu, N.-F. Prevalence and trends of obesity among school children in Taiwan-The Taipei Children Heart Study. Int. J. Obes. 2001, 25, 170-176. [CrossRef]

63. Chu, N.-F.; Pan, W.-H. Prevalence of obesity and its comorbidities among schoolchildren in Taiwan. Asia Pac. J. Clin. Nutr. 2007, 16,601 .

64. Arfai, K.; Pitukcheewanont, P.D.; Goran, M.I.; Tavaré, C.J.; Heller, L.; Gilsanz, V. Bone, Muscle, and Fat: Sex-related Differences in Prepubertal Children. Radiology 2002, 224, 338-344. [CrossRef]

65. Leonard, M.B.; Elmi, A.; Mostoufi-Moab, S.; Shults, J.; Burnham, J.M.; Thayu, M.; Kibe, L.; Wetzsteon, R.J.; Zemel, B.S. Effects of Sex, Race, and Puberty on Cortical Bone and the Functional Muscle Bone Unit in Children, Adolescents, and Young Adults. J. Clin. Endocrinol. Metab. 2010, 95, 1681-1689. [CrossRef] [PubMed]

66. Graf, C.; Schierz, O.; Steinke, H.; Körner, A.; Kiess, W.; Kratzsch, J.; Hirsch, C. The LIFE Child study team; LIFE Child study team Sex hormones in association with general joint laxity and hypermobility in the temporomandibular joint in adolescents-results of the epidemiologic LIFE child study. J. Oral Rehabil. 2019, 46, 1023-1030. [CrossRef] [PubMed]

67. Garnett, S.P.; Högler, W.; Blades, B.; Baur, L.A.; Peat, J.; Lee, J.; Cowell, C.T. Relation between hormones and body composition, including bone, in prepubertal children. Am. J. Clin. Nutr. 2004, 80, 966-972. [CrossRef]

68. Valdivia, O.D.; Ortega, F.Z.; Rodríguez, J.J.A.; Sánchez, M. Changes in flexibility according to gender and educational stage. Apunt. Med. l'esport 2009, 161, 10-17. [CrossRef]

69. Golle, K.; Muehlbauer, T.; Wick, D.; Granacher, U. Physical Fitness Percentiles of German Children Aged 9-12 Years: Findings from a Longitudinal Study. PLoS ONE 2015, 10, e0142393. [CrossRef] [PubMed]

70. Artero, E.G.; España-Romero, V.; Ortega, F.B.; Jimenez-Pavon, D.; Ruiz, J.R.; Vicente-Rodriguez, G.; Bueno, M.; Marcos, A.; Gómez-Martinez, S.; Urzanqui, A.; et al. Health-related fitness in adolescents: Underweight, and not only overweight, as an influencing factor. The AVENA study. Scand. J. Med. Sci. Sports 2010, 20, 418-427. [CrossRef]

71. Xu, Y.; Mei, M.; Wang, H.; Yan, Q.; He, G. Association between Weight Status and Physical Fitness in Chinese Mainland Children and Adolescents: A Cross-Sectional Study. Int. J. Environ. Res. Public Health 2020, 17, 2468. [CrossRef]

72. Casonatto, J.; Fernandes, R.A.; Batista, M.B.; Cyrino, E.S.; Coelho-E-Silva, M.J.; De Arruda, M.; Ronque, E.R.V. Association between health-related physical fitness and body mass index status in children. J. Child. Health Care 2016, 20, 294-303. [CrossRef] [PubMed]

73. Silva, D.A.S.; Nunes, H.E.G. Prevalence and Factors Associated with Low Aerobic Performance Levels in Adolescents: A Systematic Review. Curr. Pediatr. Rev. 2015, 11, 56-70. [CrossRef]

74. Zanini, D.; Kuipers, A.; Somensi, I.V.; Pasqualotto, J.F.; Quevedo, J.D.G.; Teo, J.C.; Antes, D.L. Relationship between body composition and physical capacities in junior soccer players. Rev. Bras. Cineantropometria Desempenho Humano 2020, 22, 22 [CrossRef]

75. Ceschia, A.; Giacomini, S.; Santarossa, S.; Rugo, M.; Salvadego, D.; Da Ponte, A.; Driussi, C.; Mihaleje, M.; Poser, S.; Lazzer, S. Deleterious effects of obesity on physical fitness in pre-pubertal children. Eur. J. Sport Sci. 2016, 16, 271-278. [CrossRef] [PubMed]

76. Thivel, D.; Ring-Dimitriou, S.; Weghuber, D.; Frelut, M.-L.; O'Malley, G. Muscle Strength and Fitness in Pediatric Obesity: A Systematic Review from the European Childhood Obesity Group. Obes. Facts 2016, 9, 52-63. [CrossRef] [PubMed]

77. Winck, A.D.; Heinzmann-Filho, J.P.; Soares, R.B.; da Silva, J.S.; Woszezenki, C.T.; Zanatta, L.B. Effects of obesity on lung volume and capacity in children and adolescents: A systematic review. Rev. Paul Pediatr. 2016, 34, 510-517. [CrossRef] [PubMed]

78. Jones, R.L.; Nzekwu, M.-M.U. The Effects of Body Mass Index on Lung Volumes. Chest 2006, 130, 827-833. [CrossRef]

79. Davidson, W.J.; Mackenzie-Rife, K.A.; Witmans, M.B.; Montgomery, M.D.; Ball, G.D.; Egbogah, S.; Eves, N.D. Obesity negatively impacts lung function in children and adolescents. Pediatr. Pulmonol. 2014, 49, 1003-1010. [CrossRef]

80. Dubern, B.; Tounian, P.; Medjadhi, N.; Maingot, L.; Girardet, J.-P.; Boulé, M. Pulmonary function and sleep-related breathing disorders in severely obese children. Clin. Nutr. 2006, 25, 803-809. [CrossRef]

81. Brunet, M.; Chaput, J.-P.; Tremblay, A. The association between low physical fitness and high body mass index or waist circumference is increasing with age in children: The 'Québec en Forme' Project. Int. J. Obes. 2006, 31, 637-643. [CrossRef]

82. Hopkins, P.M. Skeletal muscle physiology. Contin. Educ. Anaesth. Crit. Care Pain 2006, 6, 1-6. [CrossRef]

83. Ogborn, D.; Schoenfeld, B.J. The role of fiber types in muscle hypertrophy: Implications for loading strategies. Strength Cond. J. 2014, 36, 20-25. [CrossRef] 